\title{
Crime Rate in Zamboanga City: Before and During Quarantine Period
}

Justine Karl Alvarez, Fahad Hadjiri, Rina Grace Alfaro, Cheezel Book, Charloth Kayle Pelisan, Robert Clark Bechavez, Romenick Molina and Jocelyn Kong

To Link this Article: http://dx.doi.org/10.6007/IJARBSS/v11-i3/8935

DOI:10.6007/IJARBSS/v11-i3/8935

Received: 10 January 2021, Revised: 19 February 2021, Accepted: 16 March 2021

Published Online: 30 March 2021

In-Text Citation: (Alvarez et al., 2021)

To Cite this Article: Alvarez, J. K., Hadjiri, F., Alfaro, R. G., Book, C., Pelisan, C. K., Bechavez, R. C., Molina, R., \& Kong, J. (2021). Crime Rate in Zamboanga City: Before and During Quarantine Period. International Journal of Academic Research in Business and Social Sciences, 11(3), 1184-1199.

\section{Copyright: (c) 2021 The Author(s)}

Published by Human Resource Management Academic Research Society (www.hrmars.com)

This article is published under the Creative Commons Attribution (CC BY 4.0) license. Anyone may reproduce, distribute, translate and create derivative works of this article (for both commercial and non-commercial purposes), subject to full attribution to the original publication and authors. The full terms of this license may be seen at: http://creativecommons.org/licences/by/4.0/legalcode

Vol. 11, No. 3, 2021, Pg. $1184-1199$

Full Terms \& Conditions of access and use can be found at http://hrmars.com/index.php/pages/detail/publication-ethics 


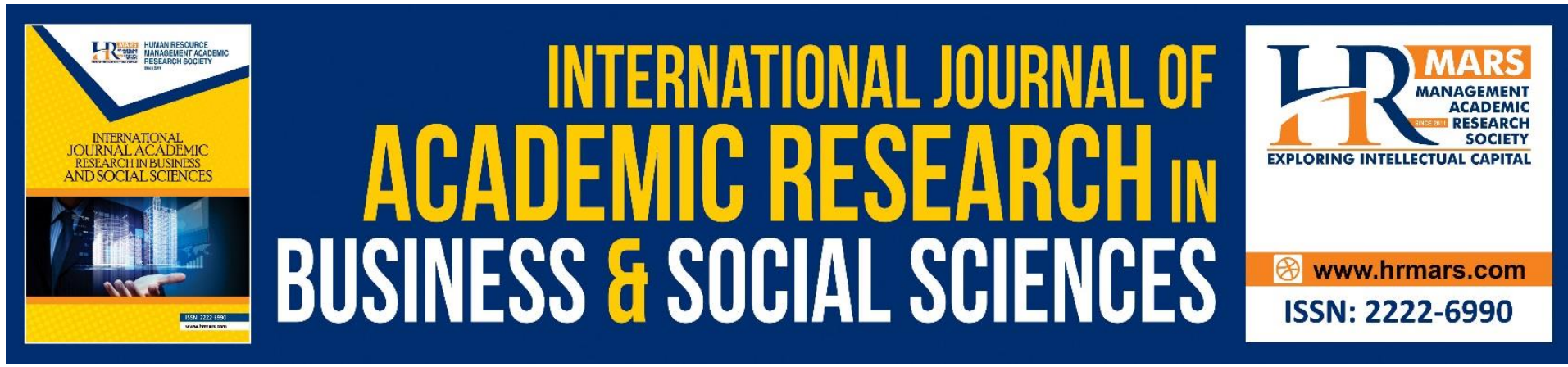

\section{Crime Rate in Zamboanga City: Before and During Quarantine Period}

${ }^{1}$ Justine Karl Alvarez, ${ }^{1}$ Fahad Hadjiri, ${ }^{1}$ Rina Grace Alfaro, ${ }^{1}$ Cheezel Book, ${ }^{1}$ Charloth Kayle Pelisan, ${ }^{1}$ Robert Clark Bechavez, ${ }^{1}$ Romenick Molina and ${ }^{1}$ Jocelyn Kong

${ }^{1}$ Senior High School Department, Zamboanga City State Polytechnic College, Zamboanga City, Philippines

Email: justinekarlalvarez@gmail.com,fadzhadjiri@gmail.com,rinagracealfaro@gmail.com, bookcheezel@gmail.com, charlothpelisan@gmail.com, clark420241@gmail.com, molina.romenick17@gmail.com, jocelyn@zcspc.edu.ph

\section{Abstract}

This study was conceptualized to compare the crime rate of Zamboanga City before and during the quarantine period. Thus, covering the month of March until October of 2016 to 2020. Secondary data analysis was utilized in the obtained data from Zamboanga City Police Office. The findings indicate that the volume of crime in the city gradually decreases from 2016 to 2020. Non-index crimes is more prevalent than index crimes in the city. In details, theft recorded as the highest index crime volume, followed by robbery and physical injury. In contrast, the volume of other non-index crime was higher than those in violation of special laws. When data were grouped according to gender, most of the crimes were committed by males. In terms of age group, culprits were ages from 30-39. Most of the crimes were committed in streets, residential places and commercial establishments. Barangays in urban areas in the city recorded with the highest crime incidents. This study may help the law enforcers to improve their security strategies. In addition, there should be crime information drive in the community using different platforms to boost awareness and create selfstrategies and self-protections among citizens.

Keywords: Crime Rate, Crime Volume, Non-index Crime, Index Crime, Quarantine Period

\section{Introduction}

A crime is an act done by an individual who is against the laws of a state or country. It happens when someone infringes the law by an overt act, omission, or neglect that can result in punishment. A person who has violated the law is said to have committed a criminal offense (Montardo, 2019). Crime is present in various forms and remains a serious concern in urban areas throughout the country (OSAC, 2020). According to the Philippine National Police (PNP), Directorate for Investigation and Detective Management, Illegal drug trade, human trafficking, murder, corruption, and domestic violence remain significant concerns. In the Philippines, the Republic Act No. 3815 of the Revised Penal Code of the Philippines serves as the supreme law that defines criminal offenses and provides the penalties for the commission 
of such crimes (Robles, 2015). Crimes are classified into index and non-index crimes for a statistical basis and to create a standardized definition of crime classification. Index crime includes crimes against persons such as homicide, murder, physical injury and rape, and crimes against property such as robbery, theft, carnapping/carjacking. On the other hand, non-index crimes are violations of special laws like illegal activities and local ordinances (Senate Planning Economic Office, 2013).

Crime destroys life in many ways. It restricts movement, thereby impeding access to possible employment and educational opportunities. It also discourages the accumulation of assets. As crime makes individuals risk-averse it retards entrepreneurial and other economic activity. Different types of crime have their own causes. Some of the key criminological theories seek to explain the causes of crime which are classified into two main approaches: Biological theories and sociological theories. Biological explanations of crime suggest that some people are 'born criminals', who are physiologically different from non-criminals. The most famous proponent of this approach is Cesare Lombroso for his theory of biological positivism. Rather than measuring physical features of the body, contemporary approaches focus on; biochemical conditions (e.g. linked to poor nourishment or hormone imbalance); Neurophysiological conditions (e.g. learning disabilities triggered by brain damage); Genetic inheritance and/or abnormality; and Intelligence. These attempts, to locate the causes of crime among individual, suggest that there are recognizable differences between offenders and non-offenders. Furthermore, sociological approaches assume that crime is shaped by factors external to the individual: their experiences within the neighborhood, the peer group, and the family. Contemporary theories of crime, place, and space include defensible space theory, which studies how the design of physical space is associated with crime; broken windows theory, which looks at the relationship between low-level disorder and crime; and routine activities theory, which deliberates how opportunities to commit crime are shaped by between people's everyday movements through space and time (SCCJR, 2016).

The Philippines has the highest rate of murder cases, among other countries in Southeast Asia as of 2013 (UNODC Homicide Statistics, 2013). Most major cities are plagued with a high occurrence of crimes, especially those living in larger urban cities in the country. Crime in the Philippines is one of the concerns that every local is facing. Due to the increase in the rate of crime in 2009, Police found challenges in Maintaining security and order. In a recent discovery, the most prevalent crime in the country was theft and physical injury. Crime against property reckoned for more than 30 percent of the country's entire crime list. Physical injury, on the other hand, accounted for around 28 percent. Compared to 2017's findings, crimes from this selection declined, recording a fourfold drop. There were around 715 crime incidents per 100,000 individuals in the Philippines as of 2014. The crime rate occurrences across the country have significantly increased over the last six years, the Cordillera Administrative Region (CAR) had around 1.2 thousand crime incidents per 100,000 individuals (Sanchez, 2020).

As of 2020, the country's order and security index score in terms of the absence of crime was almost 0.7 , where a result of one (1) meant it was effectively controlled or organized. In the past year, the Philippine National Police fortified its crime solution initiatives, which significantly helped the nation in its crime solution efficiency. Numerous joint talks about peace and security between the agencies of the Philippine National Police and Armed Forces of the Philippines could help in making a safer country (Sanchez, 2020). 
Zamboanga City in the Western part of Mindanao, Philippines was being one of the cities where the crime rate increased. The PNP reported the increased crime rate in the midyear of 2019 (Philippine Crime Statistic, 2019).

In line with the global pandemic brought by COVID-19, several prevention measures were taken. A massive community lockdown has been imposed by governments in several countries (Prasetyo, Castillo, Salonga, Sia, \& Seneta, 2020). The onset of Covid-19 has changed the lives of people, shaping the behavior of law-abiding citizens and criminals alike. In some places, violence has gone down. Initial evidence proposes one of the effects is crime rates, which appear to have dropped drastically in many communities around the world (Stickle \& Felson, 2020). For some, however, the risk has increased. Police say that they are anxious about the increase in domestic abuse since people are spending more time at home, and tempers can flare. According to Scott Decker, a criminologist that some of the violence has "shifted to inside homes". The outcome of fewer people in public is less crime (McKelvey, 2020). Now, based on the researcher's initial review of related literature, it was found out that no study has been conducted on the topic.

Thus, this study was conceptualized to compare the crime rate of Zamboanga City before and during the quarantine period. Specifically, it aimed to

1. compare the volumes of index and non-index crimes from 2016 to 2020 (March to October Period) in Zamboanga City;

2. compare the number of crimes committed in terms of gender and age group; and

3. identify the spatial patterns of crime incidents in Zamboanga City.

\section{Material and Methods}

Study Site

Zamboanga City $\left(6^{\circ} 54^{\prime} 37.01 \mathrm{~N}, 122^{\circ} 4^{\prime} 26^{\prime \prime} \mathrm{E}\right)$ is located in the southernmost tip of Zamboanga Peninsula (Region IX) in the Philippines. It is a first class and highly urbanized city, since it is the commercial and industrial center of the region. It is considered as third largest city with a total land area of 142,099.99 hectares or 1,420.99 square kilometers and sixthmost populous city with an estimated total population of 917,477 people as of 2020 reported by Philippine Statistics Authority. 


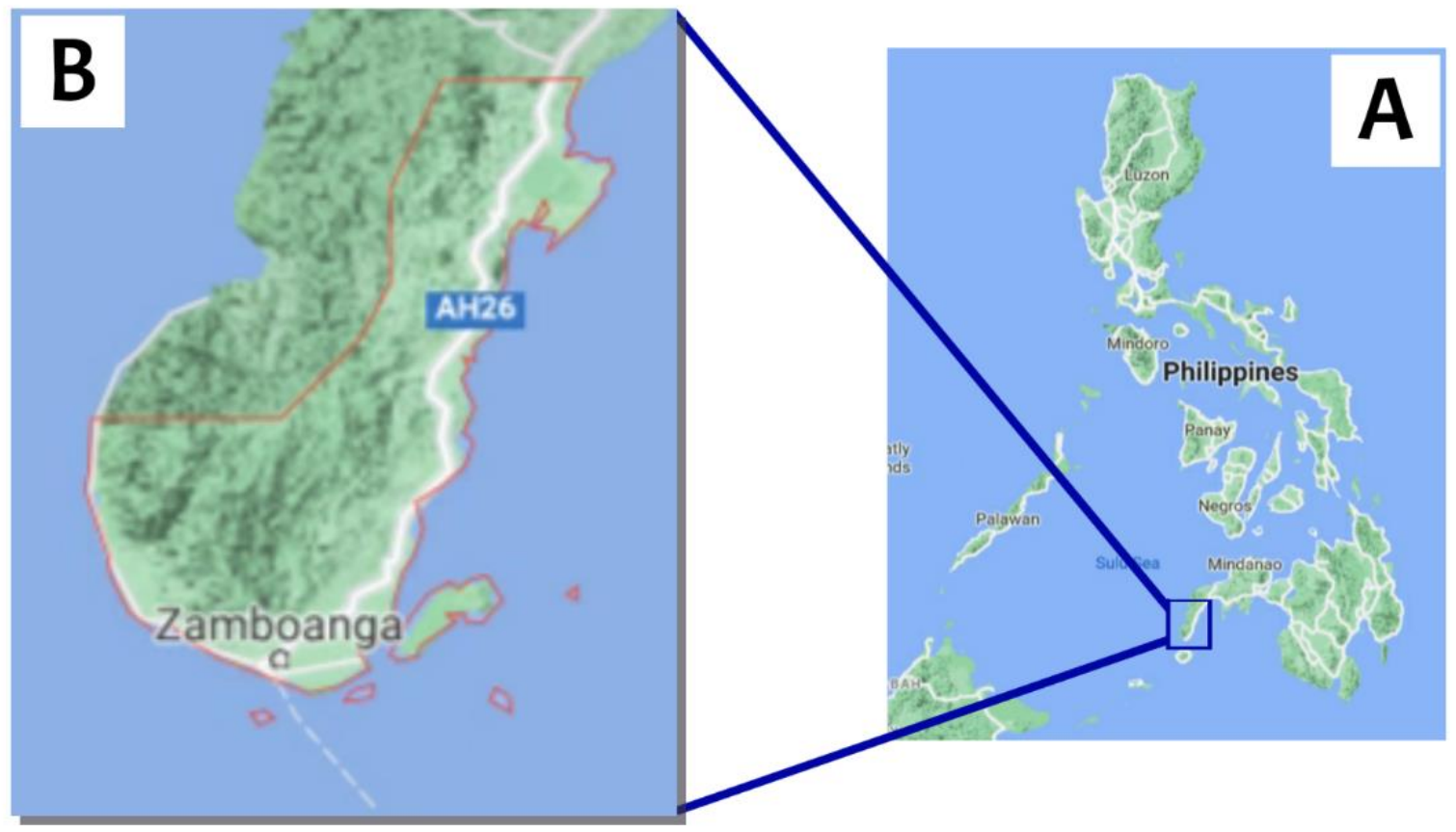

Figure 1. The Study Sites (A) Philippine Map and (B) Zamboanga City

\section{Collection of Data and Analysis}

In facilitating the gathering of data to answer the objective of the study, the researchers utilized secondary data analysis. Wherein, data were obtained from Zamboanga City Police Office (ZCPO) through a request letter submitted to Zamboanga City Police Regional Office 9 OIC, PCOL Rexmel G. Reyes.

The computation for the crime rate is done by dividing the number of reported crimes by the total population, the result is then multiplied by 100,000 (Office of the Attorney General, n.d.). This formula measures the ratio of the crime to every 100,000 residents (Talabong, 2018).

$$
\frac{\text { Crime Volume }}{\text { Population }} \times 100,000=\text { Crime rate }
$$

\section{Result and Discussion}

Zamboanga City since then, tend to experience a decrease on its crime incidents even before the COVID-19 pandemic broke out and the community lockdown was imposed (Espinosa, 2019).

The table below shows the crime rate in Zamboanga City from March to October for the calendar year of 2016 to 2020. The findings showed that the crime rate in 2016 is higher than in 2017, a most notable declined was observed in 2018 and 2019, and a significant drop was recorded in 2020. The diminish of crime volume was also observed at the national level during the first years of President Duterte's term (Xuequan, 2019). The observed decrease in crime rate in 2020 is in line with the global pandemic brought by COVID-19 outbreak, wherein it restricts the movement of people and heightened law enforcement operations that resulted in a decline in the country's crime rate during the implementation of the enhanced community quarantine. Based on the data retrieved from the PNP, from March 17 to April 30 there were only 2,676 crimes were reported nationwide, this translates to a 61-percent drop 
from the 6,712 crimes reported from February 1 to March 16 of the same year. The statistics covered the eight focus crimes of murder, homicide, physical injury, rape, robbery, theft, car theft, and motorcycle theft (Caliwan, 2020).

Table 1. The Crime Rate in Zamboanga City for 2016-2020 (March-October)

\begin{tabular}{l|lll}
\hline Year & Crime Volume & Crime Rate & Population \\
2016 & 6,936 & $795.67 \%$ & 871,711 \\
2017 & 5,525 & $625.94 \%$ & 882,672 \\
2018 & 4,939 & $552.60 \%$ & 893,771 \\
2019 & 4,574 & $505.25 \%$ & 905,281 \\
2020 & 2,189 & $238.58 \%$ & 917,477
\end{tabular}

During the first five months of President Rodrigo Duterte's presidency the volume of crimes nationwide dropped by 31 percent (CNN Philippines, 2016). A local crime watch group believes that the intensified campaign against illegal drugs of the administration added much to the decline in the number of crimes incidents that have been reported (Kyodo News, 2017). On the contrary, the number of people being killed has risen since Duterte launched his antidrug campaign (ABS-CBN News, 2016). More than 7,600 people have been slain since President Duterte unleashed a ferocious crackdown in seven months after his inauguration, more than 2,500 of them were killed in police raids and sting operations (Canoy, 2017). As a result, Duterte's war on illegal drugs leads to much international criticism such as the human rights group, Amnesty International for allegedly rampant human rights violation especially cases of extra judicial killings in the country (Kyodo News, 2017).

Barring the war on drugs of the administration, Zamboanga City shows a significant drop on its crime rate during the implementation of martial law throughout Mindanao last 2017, particularly the crime against persons and crime against property such as robbery and theft. According to ZCPO, robbers and thieves have been apparently lied low in their nefarious activities for fear of the military rule all over Mindanao (Larato, 2017).

When the COVID-19 pandemic broke out, the government enforce a community lockdown last March 17 to contain the spread of the virus (Ravelo, 2020). The lockdown includes the suspension of works and classes, transportation except for essential goods, border lockdowns and of course the precautionary measures such as social distancing, wearing mask, stay at home, wash your hands, and cover your cough (WHO, 2020). Because of stay home policy, the crime incidents in the country dropped by 47 percent during the imposition of the community quarantine. This translates to an average of 92 cases per day compared to an average of 172 cases per day during the six-month pre-quarantine period (Caliwan, 2020). 


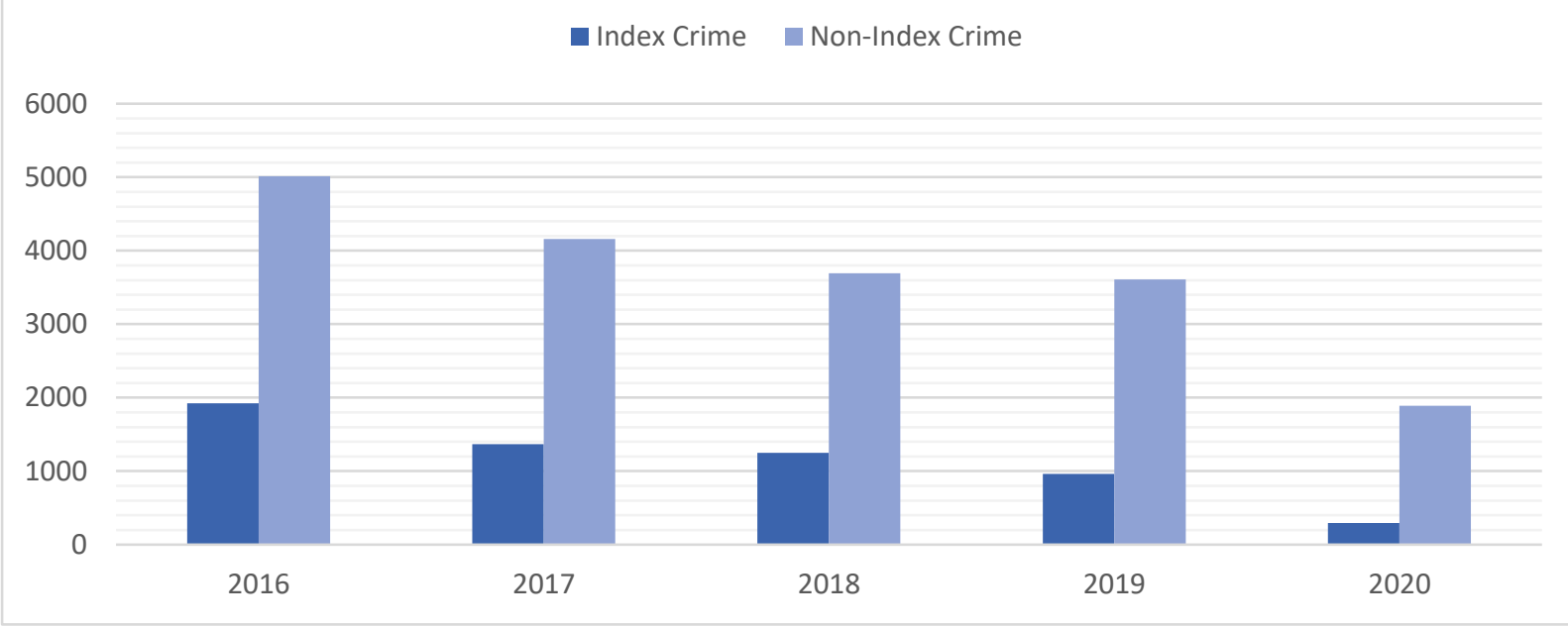

Figure 2. Index and Non-Index Crime in Zamboanga City from March to October of 2016-2020

The index and non-index crime of Zamboanga City from March to October of 2016 to 2020 is shown in Figure 2. As notice, non-index crimes in 2016 until 2020 outnumbered index crimes (Nepomuceno, 2017). Index crimes refers to crimes against person and crimes against property such as murder, homicide, rape, robbery, theft, car theft and motorcycle theft while non-index crimes are violations of special laws such as illegal logging and local ordinances (Baculinao \& Ceballos, 2019). 2016 reported the highest crime incidents in both Index and Non-Index crime. Index crime constantly declines through the years. During the pandemic period, the crime incidents of both Index and Non-Index crime dramatically drops compared to the pre-pandemic period. The ZCPO reported a biggest decrease on the index crime of the city from almost 47.23 percent or 957 cases reported this year compared to 2,026 cases reported last year. Non-Index crime makes up a huge piece on the total crime volume that reported during the community quarantine period in the city. Non-index crimes comprise of approximately 86 percent on the total crime volume reported during the quarantine period this translates to 1892 non-index crime compared to 297 index crimes.

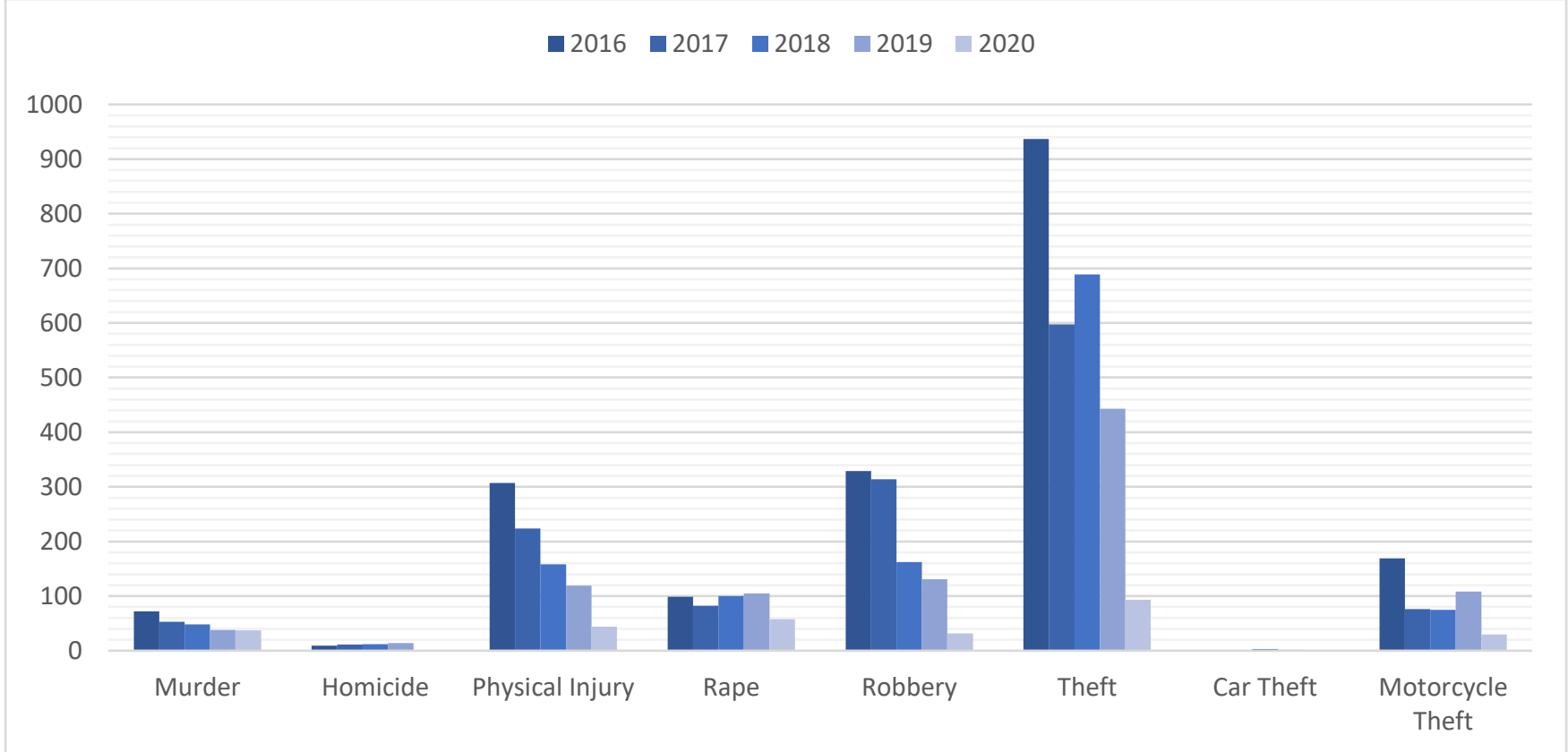

Figure 3. Comparative Index Volume for the Calendar Years 2016-2020 (March-October) 
Figure 3 shows the comparative index crime volume from March to October of 20162020. Theft reported the highest crime volume, followed by robbery and physical injury. These crimes were also observed at the national level as the top 3 most prevalent crimes among Index Crimes, these cases remarkably went down by $29.28 \% ; 21.52 \%$; and $26.34 \%$, respectively (2018-2019) (Unit Crime Periodic Report (UCPER), 2019).

During the imposition of community quarantine, theft reported the biggest decline on the number of crime incidents that reported in the city, from 443 cases in 2019 to only 93 cases in 2020. The PNP reported a decrease of 60 percent from 10,553 to 4,228 of theft incidence nationwide, while physical injury cases dropped by 38 percent, from 5,474 to 3,418 . The average daily crime rate went down from 91 to 49 incidents in Luzon, from 44 to 22 incidents in the Visayas, and from 37 to 21 incidents in Mindanao (Caliwan, 2020). According to the Police, the reduced crime incidents can be attributed to the intensified law enforcement operations to keep criminals at bay while the enhanced quarantine is being observed.

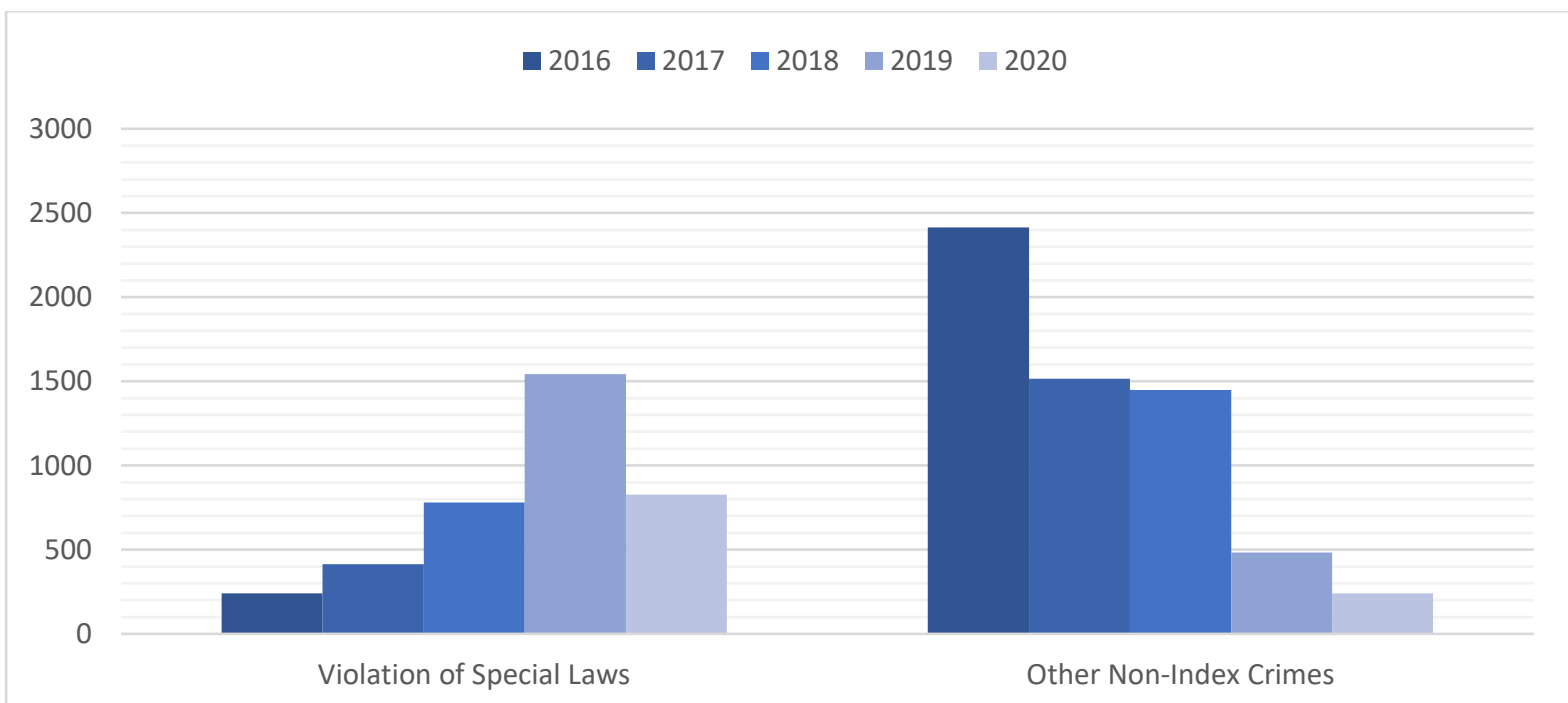

Figure 4. Comparative Non-Index Volume for the Calendar Years 2016-2020 (March-October)

The comparative non-index crime volume for March to October of 2016-2020 is displayed in Figure 4. The finding shows that the volume of other non-index crime was higher than those in violation of special laws. There was a surge on the reported number of crime incidents in terms of violation of special laws in the city, 2019 reported the highest violations among them with 1,542 cases, this escalation was caused by the 2019 midterm election were some precaution measures were taken such as the imposition of gun ban and nationwide checkpoint during the polling seasons (Martin, 2013). On the other hand, ZCPO reported that 2016 registered the highest incidents of other non-index crime in the city, the intensified campaign against illegal drug of the administration added much to the number of reported crime incidents in the city. During the quarantine period, the local police reported that for the non-index crime, reckless imprudence resulting in criminal cases like homicide, physical injury and damages to properties recorded 139 incidents or 49 percent of the total non-index crimes. Mostly of violations committed refer to violations of special laws and issuances such as traffic and anti-drugs (Larato, 2020). There were also two people offended for a violation on the Bayanihan to Heal as One Act or RA 11469 for allegedly violating the community quarantine and posting false news on social media. The number of community quarantine 
violators in the country has reached 234,720 since mid-March. Out of 234,720 violations, 118,870 were warned, 42,412 were fined and 73,438 were arrested (Caliwan, 2020). The Police Regional Office IX (PRO-9) reported that it has apprehended 445 persons for violation of the enhanced community quarantine guidelines imposed across the region since March 16. Among the 445 persons, 406 of them were apprehended for violating the curfew hours. The remaining 39 were arrested for disobedience, for violating checkpoint protocols, and for other infractions relative to the ongoing quarantine. In Zamboanga City, at least 61 tricycles and two public utility jeeps were also fined for plying routes despite the suspension of public transportation.

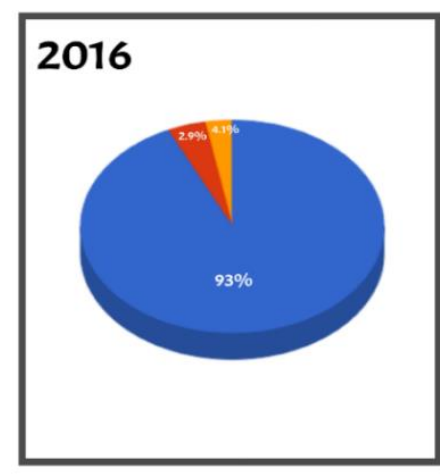

\section{LEGEND:}

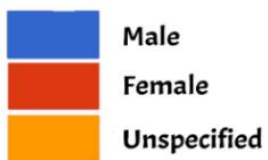

\section{7}

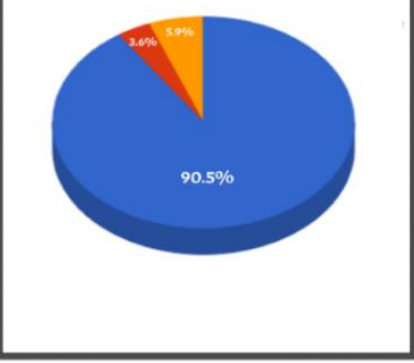

2019

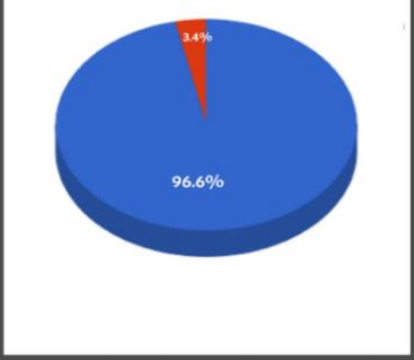

2018

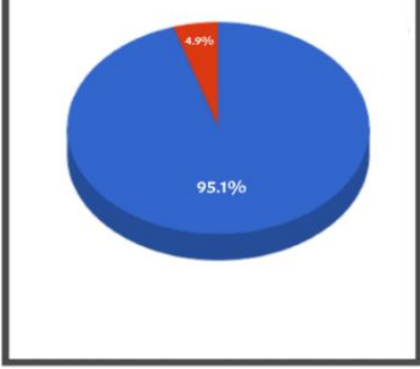

2020

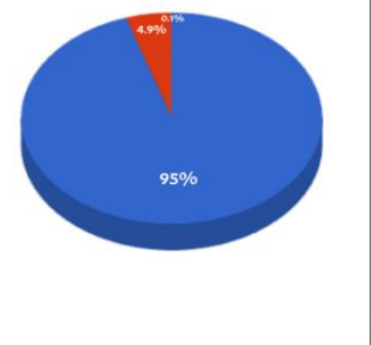

Figure 5. Crime Committed between the Calendar Years 2016-2020 (March-October) by Gender

Gender is among the best predictors of crime, particularly violent crimes (Denno, 1994). Figure 5. presents the crime incidents committed in Zamboanga City from March to October of 2016 to 2020 by gender category. The finding shows that 93.7 percent of the total crime incidents reported on the police blotter were males, followed by 4.1 percent female and 2.2 percent unspecified, while women faced the highest risk of crime victimization. Majority of "crime of violence" particularly murder was committed by males with over 98 percent of the total crime incidents reported from March to October of 2016-2020. According to the Philippine National Police, Crimes of Violence refers to crimes such as murder, homicide, kidnapping/abduction, bombings, sexual assault and other criminal incidents that put lives in danger. Murder, is the most serious of all "violent crimes". A study suggests that males are in general more aggressive than females (Hapkiewicz \& Stone, 1974), even before the preschool years (Denno, 1994). However, most theory and explanation of crime are gender blind (Denno, 1994). Moreover, male also reported the most numbered of drug related offenders in the city. The result was also similar to the findings of Simbulan et al (2019) (Simbulan et al, 2019). 
Table 2. Age Distribution of Crime in Zamboanga City from March to October of 2016-2020

\begin{tabular}{l|lllll}
\hline Age Group & $\mathbf{2 0 1 6}$ & $\mathbf{2 0 1 7}$ & $\mathbf{2 0 1 8}$ & $\mathbf{2 0 1 9}$ & $\mathbf{2 0 2 0}$ \\
$0-9$ & 1 & 3 & 3 & 1 & \\
$10-19$ & 293 & 292 & 322 & 368 & 133 \\
$20-29$ & 863 & 879 & 1,071 & 1,125 & 546 \\
$30-39$ & 1,010 & 980 & 1,133 & 1,277 & 689 \\
$40-49$ & 581 & 565 & 692 & 771 & 422 \\
$50-59$ & 185 & 232 & 310 & 342 & 217 \\
$60-69$ & 75 & 77 & 99 & 121 & 60 \\
$70-79$ & 6 & 16 & 16 & 30 & 10 \\
$80-89$ & & 2 & 2 & 1 & 1 \\
$90-99$ & & & & 1 & \\
Unspecified & 3,882 & 2,469 & 1,291 & 537 & 111
\end{tabular}

Table 2. presents the age distribution of crime reported in Zamboanga City from March to October of 2016 to 2020. The finding indicates that from March to October of 2016 to 2020 , the age group from 30 to 39 committed the most crime incidents in the city. During the implementation of the community quarantine, the crime incidents reported by the police in terms of age group declined by almost 50 percent compared to the pre-pandemic period. The declined of crime incidents reported by age group are consequences of the ongoing community quarantine protocol. Thus, the total crime volume was declined.

Table 3. Spatial Patterns of Crime Incidents in Zamboanga City from March to October of 2016-2020

\begin{tabular}{l|lllll}
\hline Place of Commission & $\mathbf{2 0 1 6}$ & $\mathbf{2 0 1 7}$ & $\mathbf{2 0 1 8}$ & $\mathbf{2 0 1 9}$ & $\mathbf{2 0 2 0}$ \\
Recreational Places & $0.04 \%$ & $0.09 \%$ & $0.22 \%$ & $0.31 \%$ & $0.27 \%$ \\
Schools & $0.14 \%$ & $0.09 \%$ & $0.25 \%$ & $0.62 \%$ & $0.09 \%$ \\
Commercial Establishments & $1.11 \%$ & $0.73 \%$ & $4.25 \%$ & $6.55 \%$ & $2.83 \%$ \\
Residential Place & $5.36 \%$ & $7.45 \%$ & $17.43 \%$ & $28.33 \%$ & $26.18 \%$ \\
Office/ Workplace & $0.06 \%$ & $0.2 \%$ & $0.18 \%$ & $0.37 \%$ & $0.32 \%$ \\
Streets & $6.29 \%$ & $5.81 \%$ & $14.51 \%$ & $23.51 \%$ & $33.17 \%$ \\
Other Places & $87 \%$ & $85.62 \%$ & $63.16 \%$ & $40.31 \%$ & $37.14 \%$
\end{tabular}

Table 3. shows the spatial patterns of crime incidents that reported in Zamboanga City from March to October of 2016-2020. The result shows that crime incidents were usually taking place along the streets, in residential places, and in commercial establishments, while other places comprises the hospitals, religious places, and etc. Vehicular accident, buy bust operation, and theft were among the most committed crime along the street. According to a study conducted in 2009 by Adrian Tamayo, mostly of vehicular accidents occurs caused by driver's errors (26\%), mechanical defect (12\%), over speeding (18\%), drinking spree before driving (1\%), damaged roads (5\%) (Tamayo, 2009). In Zamboanga City, 64 percent of offenses in vehicular accidents were reckless imprudence resulted to damage to property; $30 \%$ were resulted to physical injury and $5 \%$ were resulted to homicide. Meanwhile, buy bust operation and other drug related incidents were among the most committed crimes in residential places in the city, based on the police blotter retrieved from ZCPO, from 2016 to 2019 the incidents spikes to over 246 percent, one of the reasons were the intensified crackdown of the government against illegal drugs that commenced last 2016 (Mogato, 2017). Compare to 
2016 and 2017, 2020 reported the most numbered of crime incidents committed in residential places, experts believe that domestic violence and other crimes committed at home will rise due to the stay at home policy amidst the pandemic. Likewise, 2020 also reported the most numbered of crime incidents committed on commercial or business establishments compared to 2017 were majority of them were shoplifting. A study suggests that shoplifting spikes during the early years of pandemic, factors such as unemployment or lack of job opportunities in the midst of the pandemic tends people to steal food for their survival (Bhattarai \& Denham, 2020).

Table 4. Top 5 Barangays in Zamboanga City with Highest Total Crime Volume from March-October (2016-2020)

\begin{tabular}{l|llllll}
\hline Barangay & $\mathbf{2 0 1 6}$ & $\mathbf{2 0 1 7}$ & $\mathbf{2 0 1 8}$ & $\mathbf{2 0 1 9}$ & $\mathbf{2 0 2 0}$ & Total \\
Santa Maria & 437 & 465 & 391 & 464 & 229 & 1,986 \\
Tetuan & 490 & 441 & 247 & 176 & 55 & 1,490 \\
Putik & 343 & 300 & 278 & 268 & 100 & 1,289 \\
Calarian & 346 & 283 & 291 & 252 & 100 & 1,272 \\
Divisoria & 118 & 211 & 213 & 175 & 206 & 923
\end{tabular}

The Top 5 Barangays in Zamboanga City with the highest total crime volume recorded from March-October of 2016-2020 is shown in Table 4. Out of 24,153 total crime incidents recorded from March to October of 2016-2020 in the city, Barangay Sta. Maria recorded the highest number of crime incidents at 1,986 or $8.22 \%$, followed by Barangay Tetuan at 1,490 or $6.16 \%$, Barangay Putik at 1,289 or $5.33 \%$, Barangay Calarian at 1,272 or 5.26 and Barangay Divisoria at number 5 with 923 total cases or $3.82 \%$ while Island Barangays such as Landang Laum, Landang Gua, Tumalutab and Pangapuyan only recorded one cases throughout 2016 to 2020. The correlation between population density and crime may affect the surge of crime volume on a particular place (NCJRS, n.d.). Based on a study conducted by 2000 Uniform Crime Reportes (UCR) on 1,294 cities with populations over 25,000, there is a significant positive relationship between crime rate and population size, cities with higher population reported the higher crime rates (Nolan, 2004). Other factors may also attribute on different crime patterns, such as poverty and unemployment (NCJRS, n.d.; BBC, n.d.). There was a significant drop on the number of crime incidents before and during the implementation of the community quarantine period in the city, the top five barangays that reported the highest crime volume in 2019 was reduced from 50 to 60 percent on its crime volume during the pandemic period. 


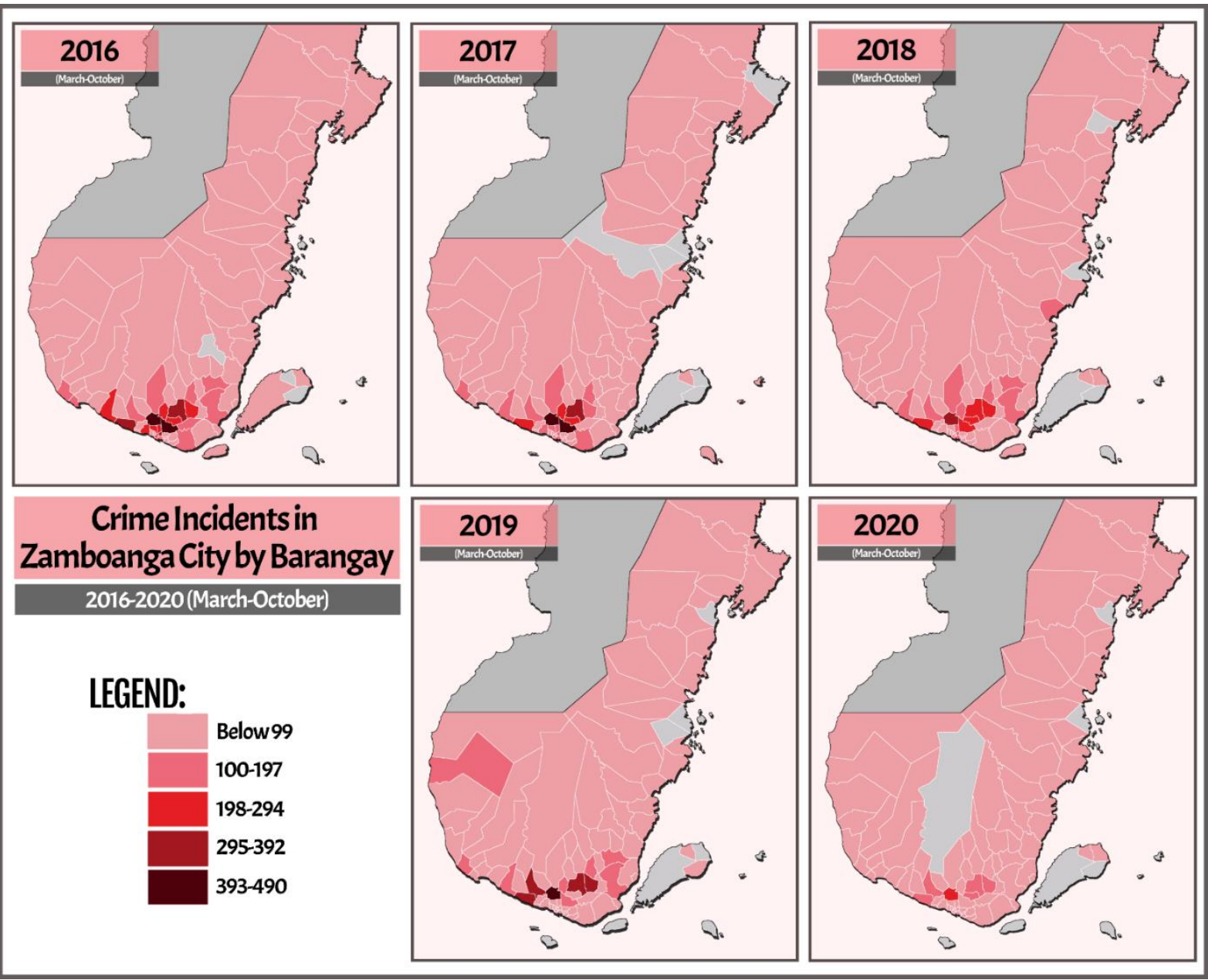

The crime incidents in Zamboanga City per barangay from 2016-2020 (March-October) is presented in Figure 6. As what observed on the map, majority of the barangays especially in rural areas reported only 1-99 cases from 2016-2020 (March-October), while barangays concentrated in urban areas reported crime incidents ranging from 100 to 490 cases per year. According to a study tested with cross-sectional Japanese data for 1970 conducted by Ladbrook, 1988, there are three sociological explanations for why crime rates in urban areas are higher than those in rural areas; (1) the degree of urbanization and populated density, (2) the greater rates of migration and population growth in urban populations, and (3) the differences in demographic structures between urban and rural areas, urban areas having greater proportions of young people (Ladbrook, 1988). During the community quarantine in the city, majority of barangays only reported 1-294 cases. The impact of COVID-19 pandemic on crime incidents reported in Zamboanga City by barangay were apparent to the color of the map.

\section{Conclusion}

Crime is one of the concern in Zamboanga City. Base on the secondary data analysis, the crime rate in 2016 is higher than in 2017, a most notable declined was observed in 2018 and 2019, and a significant drop was recorded in 2020. The volume of non-index crimes reported in the city outnumbered index crimes. Among index crimes, theft reported the highest crime volume, followed by robbery and physical injury. Meanwhile, the volume of non-index crime was higher than those in violation of special laws. In addition, 93.7 percent 
of the total crime incidents reported on the police blotter were males, followed by 4.1 percent female and 2.2 percent unspecified. Adults with ages ranging from 30-39 committed the most number of crime incidents in the city. Most of the crimes reported in the city were usually taking place along the streets, in residential places and in commercial establishments. The findings showed that the barangays in urban areas has highest crime volume.

This study may help the law enforcers to formulate new strategies in reducing crime incidents. More so, informing and educating the community about crime volume and rate in the city may boost awareness and create self-strategies and self-protections among citizens.

\section{References}

ABS-CBN News. (2016). PNP: Crime rate down, but murder rate up. Retrieved Janaury 21, 2021, from ABS-CBN News: https://news.abs-cbn.com/news/12/19/16/pnp-crimerate-down-but-murder-rate-up

Baculinao, R. S., \& Ceballos, a. R. (2019). An Analysis on the Location and Type of Index Crimes in the Philippines. Retrieved January 20, 2021, from Philippine Statistic Authority: https://psa.gov.ph/sites/default/files/8.6.2\%20An\%20Analysis\%20on\%20the\%20Loc ation\%20and\%20Type\%20of\%20Index\%20Crimes\%20in\%20the\%20Philippines.pdf

BBC. (n.d.). Geography of crime. Retrieved January 20, 2021, from BBC: https://www.bbc.co.uk/bitesize/guides/zytycdm/revision/2

Bhattarai, A., \& Denham, H. (2020). Stealing to survive: More Americans are shoplifting food as aid runs out during the pandemic. Retrieved January 26, 2021, from The Washington Post:

https://www.washingtonpost.com/business/2020/12/10/pandemic-shopliftinghunger/

Caliwan, C. L. (2020). PH focus crimes down by $47 \%$ in 6 months of quarantine: PNP. Retrieved January 21, 2021, from Philippine News Agency: https://www.pna.gov.ph/articles/1115847

Caliwan, C. L. (2020). PH posts 51\% drop in crime rate since start of quarantine. Retrieved January 21, 2021, from Philippine News Agency: https://www.pna.gov.ph/articles/1109725

Caliwan, C. L. (2020). PH posts 61\% drop in crime rate since start of ECQ. Retrieved January 21, 2021, from Philippine News Agency: https://www.pna.gov.ph/articles/1101577

Canoy, J. (2017). PNP shifts focus: Now, it's war vs 7 crimes. Retrieved January 21, 2021, from ABS-CBN News: https://news.abs-cbn.com/news/02/06/17/pnp-shifts-focus-now-itswar-vs-7-crimes

CNN Philippines. (2016). Overall crime rate falls in first five months of Duterte presidency. Retrieved January 21, 2021, from CNN Philippines:

https://cnnphilippines.com/news/2016/12/20/Overall-crime-rate-falls-in-first-fivemonths-of-Duterte-presidency.html

Denno, D. W. (1994). Gender, Crime, and the Criminal Law Defenses. Journal of Criminal Law and Criminology, 85(1). Retrieved January 25, 2021

Espinosa, M. C. (2019). Zambo City remains peaceful, police report. Retrieved January 19, 2021, from Philippine News Agency: https://pia.gov.ph/news/articles/1016894

Garcia, B. (2018). Zamboanga City crime volume declines by 38\%. Retrieved January 19, 2021, from SunStar Philippines:

https://www.sunstar.com.ph/article/1750931/Zamboanga/Local-News/Zamboanga-

City-crime-volume-declines-by-38 
Garcia, T. J. (2020). Zambo crime rate drops amid Covid-19 crisis. Retrieved January 19, 2021, from Philippine News Agency: https://www.pna.gov.ph/articles/1098363

Hapkiewicz, W. G., \& Stone, R. D. (1974). The effect of realistic versus imaginary aggressive models on children's interpersonal play. Child Study Journal, 21(5), 47-58. Retrieved January 19, 2021

Kyodo News. (2017). Philippines' crime rate falls 13 percent in 2016. Retrieved January 21, 2021, from ABS-CBN News: https://news.abs-cbn.com/news/02/13/17/philippinescrime-rate-falls-13-percent-in-2016

Ladbrook, D. A. (1988). Why are crime rates higher in urban than in rural areas? - Evidence from Japan. Australian \& New Zealand Journal of Criminology, 21(2), 81-103. Retrieved March 2, 2021, from https://journals.sagepub.com/doi/abs/10.1177/000486588802100203?journalCode =anja

Larato, V. (2017). Zambo crime rate drops as martial law continues. Retrieved January 21, 2021, from Beng Climaco FB Page: https://www.facebook.com/bengclimaco/posts/10154688731438014:0

Larato, V. (2020). ZCPO reports 33\% drop. Retrieved January 21, 2021, from City Government of Zamboanga: https://www.facebook.com/zambocitygovt/posts/654468018559192

Martin, K. A. (2013). Are there really more crimes in PH during election years. Retrieved March 7, 2021, from ABS-CBN News: https://news.abs-cbn.com/focus/02/22/13/are-therereally-more-crimes-ph-during-election-years

McKelvey, T. (2020). BBC. Retrieved November 7, 2020, from BBC: https://www.bbc.com/news/world-us-canada-52416330

Mogato, M. (2017). Philippines war on drugs and crime intensifies, at least 60 killed in three days. Retrieved January 26, 2021, from Reuters: https://www.reuters.com/article/usphilippines-drugs-idUSKCN1AXOBO

Montardo, C. (2019). ThoughtCo. Retrieved September 26, 2020, from ThoughtCo: https://www.thoughtco.com/what-is-a-crime-970836

NCJRS. (n.d.). Relationship between Population Density and Crime Rates. Retrieved January 19, 2021, from Nationa Criminal Justice Reference Service:

https://www.ncjrs.gov/App/Publications/abstract.aspx?ID=99314\#: :text=Thus\%2C \%20while\%20population\%20density\%20may,stronger\%20influence\%20on\%20crime \%20patterns.

Nepomuceno, P. (2017). Non-index crimes make up large part of total crime volume: PNP. Retrieved January 18, 2021, from Philippine News Agency:

https://www.pna.gov.ph/articles/1015344

Nolan, J. J. (2004). Establishing the statistical relationship between population size and UCR crime rate: Its impact and implications. Journal of Criminal Justice, 547 - 555. Retrieved January 20, 2021, from https://theipti.org/wpcontent/uploads/2012/02/covariance.pdf

Office of the Attorney General. (n.d.). Computational Formula. California. Retrieved March 2, 2021, from OAG.ca.gov: oag.ca.gov

OSAC. (2020). Overseas Security Advisory Council (OSAC). Retrieved September 26, 2020, from Overseas Security Advisory Council (OSAC): https://www.osac.gov/Country/Philippines/Content/Detail/Report/b5c8b11f-5b1b4180-b911- 
18307766f680\#: :text=Crime\%20continues\%20to\%20remain\%20a,to\%20local\%20au thorities\%20in\%202019.

Prasetyo, Y. T., Castillo, A. M., Salonga, L. J., Sia, J. A., \& Seneta, J. A. (2020). Factors affecting perceived effectiveness of COVID-19 prevention measures among Filipinos during Enhanced Community Quarantine in Luzon, Philippines: Integrating Protection Motivation Theory and extended Theory of Planned Behavior. International Journal of Infectious Diseases, 312-323. Retrieved November 7, 2020

Ravelo, J. L. (2020). To contain the spread of coronavirus, Manila grapples with lockdown. Retrieved January 21, 2021, from Devex: https://www.devex.com/news/to-containthe-spread-of-coronavirus-manila-grapples-with-lockdown-96823

Robles, M. A. (2015). Tightening the Net: The Legal Link between Illegal, Unreported and Unregulated Fishing and Transnational Crime under International Law. Ocean Yearbook Online, 144-165. Retrieved October 22, 2020

Sanchez, M. J. (2020). Statista. Retrieved Retrieved on September 26, 2020, from Statista: https://www.statista.com/topics/6994/crime-in-the-philippines/

SCCJR. (2016). The Scottish Center for Crime and Justice Research. Retrieved October 23, 2020, from The Scottish Center for Crime and Justice Research: http://www.sccjr.ac.uk/wpcontent/uploads/2016/02/SCCJR-Causes-of-Crime.pdf

Senate Planning Economic Office. (2013). Senate of the Philippines. Retrieved on September 26, 2020, from Senate of the Philippines:

http://legacy.senate.gov.ph/publications/AAG\%202013-05\%20-

\%20Crime\%20Statistics.pdf

Simbulan, N., Estacio, L., Maligaso, C. D., Herbosa, T., \& Withers, M. (2019). The Manila Declaration on the Drug Problem in the Philippines. Annals of global health, 5(1). Retrieved from https://doi.org/10.5334/aogh.28 Retrieved January 25, 2021

Stickle, B., \& Felson, M. (2020). Crime Rates in a Pandemic: the Largest Criminological Experiment in History. American Journal of Criminal Justice, 525-536. Retrieved October 22, 2020, from https://doi.org/10.1007/s12103-020-09546-0

Talabong, R. (2018). Is your city safe? Understanding PNP Crime Statistics. Retrieved March 2, 2021, from Rappler: https://www.rappler.com/newsbreak/iq/understanding-pnpcrime-statistics

Tamayo, A. M. (2009). Occurrence of Traffic Accidents in the Philippines: An Application of Poisson Regression Analysis. SSRN Electronic Journal. doi:10.2139/ssrn.1438478 Retrieved January 26, 2021

Unit Crime Periodic Report (UCPER). (2019). QUICK LOOK CRIME ENVIRONMENT REPORT. Retrieved January 21, 2021, from Directorate for Investigation and Detective Management-PNP:

http://didm.pnp.gov.ph/images/sidebar_pdf/crimestat/Crime_Environment_2018_v s_2019_.pdf

UNODC Homicide Statistics. (2013). UNODC Homicide Statistics. Retrieved October 22, 2020, from UNODC Homicide Statistics:

https://www.unodc.org/documents/gsh/pdfs/2014_GLOBAL_HOMICIDE_BOOK_web .pdf

WHO. (2020). Coronavirus disease (COVID-19) advice for the public. Retrieved January 22, 2021, from World Health Organization:

https://www.who.int/emergencies/diseases/novel-coronavirus-2019/advice-forpublic 
INTERNATIONAL JOURNAL OF ACADEMIC RESEARCH IN BUSINESS AND SOCIAL SCIENCES

Vol. 11, No. 3, 2021, E-ISSN: 2222-6990 @ 2021 HRMARS

Xuequan, M. (2019). Crime in Philippines "remains on a downtrend": Philippines police. Retrieved January 24, 2021, from Xinhua: http://www.xinhuanet.com/english/201908/10/c_138297141.htm 